\title{
PENGGUNAAN AWIK-AWIK SEBAGAI MODEL "ECOPEDAGOGY" DALAM PEMBELAJARAN IPS
}

\author{
Dodik Kariadi $^{1)}$, Enok Maryani ${ }^{2)}$, Helius Sjamsuddin ${ }^{3)}$, \& Mamat Ruhimat ${ }^{4)}$ \\ ${ }^{1)}$ STKIP Singkawang, Singkawang, Indonesia \\ E-mail: kariadidodik@gmail.com \\ ${ }^{2)}$ Universitas Pendidikan Indonesia, Bandung, Indonesia \\ ${ }^{3)}$ Universitas Pendidikan Indonesia, Bandung, Indonesia \\ ${ }^{4)}$ Universitas Pendidikan Indonesia, Bandung, Indonesia
}

\begin{abstract}
Abstrak. Awig-awig pada dasarnya adalah peraturan yang harus di patuhi oleh masyarakat sebagai mana aturan ini disebut sebagai aturan adat dan aturan lokal. Tujuan dari artikel ini adalah untuk mengetahui prinsip-prinsip implementasi Awik-awiksebagai model "ecopedagogy" dalam pendidikn IPS dan plikasi Awik-awiksebagai model "ecopedagogy" ke dalam Pembelajaran IPS.Tulisan ini diharapkan dapat bermanfaat untuk menjelaskan (to explain), tentangPenggunaan Awik-Awik Sebagai Model "Ecopedagogy" dalam Pembelajaran IPS. Hasil penelitian menunjukkan bahwa melalui awik-awik sebagai model "ecopedagogy" dalam pembelajaran IPS yang dilaksanakan di sekolah, program lingkungan hidup dapat diimplementasikan dalam kurikulum sekolah. Implementasi program lingkungan hidup dalam kurikulum diharapkan dapat menciptakan perubahan, baik perubahan sikap maupun pengetahuan serta mampu membentuk kepribadian peserta didik untuk menjadi lebih baik. Upaya yang dilakukan sekolah untuk mewujudkan kepedulian peserta didik terhadap lingkungan hidup yakni, sekolah berupaya untuk memasukkan program lingkungan hidup ke dalam kurikulum.
\end{abstract}

Kata Kunci : Awik-Awik, Ecopedagogy, Pembelajaran IPS

\section{PENDAHULUAN}

Di seputaran daerah Nusa Tenggara dan Bali, ada istilah Awik-Awik, yang merujuk pada keberadaan peraturan lokal setempat. Awik-Awik adalah hukum adat yang sudah diterapkan secara turun-temurun, berisi larangan-larangan beserta hukuman-hukumannya, bersifat mengikat terhadap semua penduduk di daerah tersebut. Hukuman atas pelanggaran awik-awik bervariasi mulai dari denda yang bisa berupa tenaga, harta, penyitaan tanah, sampai dengan yang berat sekali seperti diasingkan dari masyarakat.

Aturan-aturan yang dibuat oleh pemerintah belum bisa dilaksanakan dengan baik oleh masyarakat karena kesadaran masyarakat yang belum begitu peduli terhadap aturan yang dibuatkan oleh pemerintah sehingga tokoh masyarakat mempunyai inisiatif untuk membuat awig-awig secara bermusawarah dengan masyarakat yang ada di masyarakat, dengan membuat awig-awig secara bersama-sama masyarakat merasa terikat untuk tidak melakukan perusakan, karena mempunyai sanksi-sanksi bilamana melakukan hal-hal yang bisa merusak atau mencemari lingkungan yang ada di sekitar, oleh sebab itu awig-awig ini harus di patuhi secara baik sesuai dengan kesepakatan yang telah dibuat.

Pentingnya keberdaan awik-awik menjadi sebuah pontensi yang bisa menjadi garapan dunia pendidikan sehingga keberlangsungannya tetap terjaga. Dengan demikian harus awik-awik disandingkan dengan "ecopedagogy" maka akan mampu menciptakan kesadaran ekologis, dimana kesadaran ini tidaklah dibangun melalui sebuah proses pendidikan yang hanya bersifat transfer of knowledge, melainkan sebuah proses pembelajaran yang menempatkan peserta didik sebagai subjek aktif dalam pembelajaran. Pendidikan yang membangun kesadaran dan kecerdasan ekologis dengan berorientasi pada transfer of knowledge hanya akan membuat peserta didik hanya sebatas memiliki pengetahuan tentang lingkungan, dan kurang memiliki kesadaran dan kepedulian terhadap lingkungan 
(Muhaimin, 2015). Hal inipun berdampak buruk pada karakter siswa yang pada umumnya belum bersikap dan berkelakuan ramah terhadap lingkungan (Soemarwoto, 2001; Supriatna, 2016). Hal ini tampak dengan bertebarannya sampah dilingkungan sekolah, beralih fungsinya toilet menjadi tempat buang tisu, pembungkus dan lainlain seperti dapat disaksikan disebagian besar sekolah menunjukkan bahwa kalangan terdidik tidak memiliki kompetensi/ kecerdasan ekologis (Muhaimin, 2015).

Ekopedagogik dapat diartikan sebagai gerakan akademik untuk menyadarkan para peserta didik menjadi seorang individu yang memiliki pemahaman, kesadaran dan keterampilan hidup selaras dengan kepentingan pelestarian alam (Kahn, 2010). Dalam pengertian berbeda (Gadotti, 2010) berpendapat bahwa ekopedagogik merupakan sebuah pendekatan dalam pembelajaran yang menjadikan para siswa sebagai pembelajar yang mandiri, otonom, mampu mengembangkan potensi belajar berdasarkan pengalaman yang dibawa dari luar kelas serta menyadari bahwa setiap tindakannya berdampak pada diri dan lingkungannya. Sebagai sebuah pendekatan pembelajaran, ekopedagogik didukung oleh teori kritis dan pedagogik kritis (Supriatna, 2016). Oleh sebab itu, merujuk kepada informasiinformasi di atas, maka makalah ini memiliki tujuan untuk mengetahui penggunaan awik-awik sebagai model "ecopedagogy" dalam pembelajaran IPS sehingga menuju kepada upaya pemanfaatan sumber daya alam yang berkelanjutan baik secara ekonomi dan ekologi.

\section{HASIL DAN PEMBAHASAN}

\section{A. Kajian Tentang Awik-awik}

\section{Konsep Awik-awik}

Awig-awig sebagai dasar peraturan yang harus di patuhi oleh masyarakat sebagai mana aturan ini disebut sebagai aturan adat dan aturan lokal. Tentang hukum adat, Soepomo menyatakan bahwa sistim tersebut didasarkan pada suatu kebutuhan yang berdasarkan atas dasar satu kesatuan alam pikiran. Untuk menyelami sistem tersebut maka seseorang harus menyelami sistem tadi, maka seseorang harus menyelami dasar-dasar pemikiran yang hidup didalam masyarakat. Untuk itu harus diteliti susunan persekutuan-persekutuan hukum dilapangan rakyat yaitu organisasi desa, hutan dan laut. Selanjutnya soepomo berkata bahwa: berlakunya suatu hukum adat adalah tampak dalam putusan kepala desa, keputusan pegawai agama, dan masing-masing dalam lapangan kopetensinya (Soerjono: 5960: 2006).

Awik-awik Desa Adat adalah keseluruhan hukum yang mengatur tata cara kehidupan bagi warga desa adat beserta sanksi dan aturan pelaksanaanya. Awik-awikberasal dari kata a artinya tidak dan wik yang artinya rusak, sedangkan awig artinya tidak rusak atau baik. Awik-awik artinya sesuatu yang menjadi baik. Konsepsi inilah yang dituangkan ke dalam aturan-aturan baik secara tertulis maupun tidak tertulis sehingga menimbulkan suatu pengertian, bahwa Awik-awik adalah peraturan-peraturan hidup bersama bagi krama desa di desa adatnya, untuk mewujudkan kehidupan yang aman, tentram, tertib, dan sejahtera di desa adat. Awik-awik itu memuat aturan-aturan dasar yang menyangkut wilayah adat, krama desa adat, keagamaan serta sanksi (Pujosewoyo, 1983).

Kusumadi

Pujosewoyo

(1983), menjelaskan: Awik-awik Desa Adat merupakan keseluruhan hukum yang mengatur tata cara kehidupan bagi warga desa adat beserta sanksi dan aturan pelaksanaanya. Awik-awikberasal dari kata a artinya tidak dan wig yang artinya rusak, sedangkan awig artinya tidak rusak atau baik. Awik-awik artinya sesuatu yang menjadi baik. Konsepsi inilah yang dituangkan ke dalam aturan-aturan baik secara tertulis maupun tidak tertulis sehingga menimbulkan suatu pengertian, bahwa Awik-awik adalah peraturan-peraturan hidup bersama bagi krama desa di desa adatnya, untuk mewujudkan kehidupan yang aman, tentram, tertib, dan sejahtera di desa adat. Awik-awik itu memuat aturan-aturan dasar yang menyangkut wilayah adat, krama desa adat, keagamaan serta sanksi.

Sedangkan menurut Edi Muhamad Jayadi dan Soemarno, menjelaskan bahwaawik-awik 
desa adalah kearifan lokal dalam bentuk aturan-aturan adat (hukum adat). Sedangkan Mukhtar, dkk. menjelaskan bahwa, "Awikawik desa adalah kearifan lokal yang dimiliki oleh masyarakat Bali dan Lombok yang berisi nilai-nilai atau norma-norma yang tumbuh dan berkembang, menyatu dengan budaya, kepercayaan yang diekpresikan dengan mitos dan simbol-simbol tertentu, serta diwariskan secara turun-temurun".

Dalam setiap masyarakat, akan dijumpai setiap perbedaan antara pola-pola perilakuyang berlaku didalam masyarakat dengan pola-pola perilaku perikelakuan yang dikehendaki oleh kaidah kaidah-kaidah hukum. Adalah suatu keadaan yang tidak dapat dihindari apabila terkadang timbul suatu ketegangan sebagai akibat perbedaan-perbedaan tersebut di atas. Dengan demikian, maka tidaklah terlalu mengherankan mengapa hukum kadangkadang tidak berhasil mengusahakan atau bahkan memaksakan agar masyarakat menyusuaikan tingkah lakunya pada hukum yang telah diperlakukan.

Apa hal ini berarti bahwa hukum selalu tertinggal dibelakang perubahan-perubahan sosial dan kebudayaan di dalam masyarakat (William F. Ogburn 1966: 200). Hukum tertinggal, apa bila hukum tersebut tidak dapat memenuhi kebutuhan masyarakat pada suatu tempat tertentu. Misalnya, dengan perkembangan teknologi dibidang tenaga nuklir untuk maksud-maksud damai, hukum (internasional, publik dan lain-lain) mungkin tertinggal. (Soerjono: 23: 2006).

Aturan-aturan yang dibuat oleh pemerintah belum bisa dilaksanakan dengan baik oleh masyarakat karena kesadaran masyarakat yang belum begitu peduli terhadap aturan yang dibuatkan oleh pemerintah sehingga tokoh masyarakat mempunyai inisiatif untuk membuat awig-awig secara bermusawarah dengan masyarakat yang ada di masyarakat, dengan membuat awig-awig secara bersamasama masyarakat merasa terikat untuk tidak melakukan perusakan, karena mempunyai sanksi-sanksi bilamana melakukan hal-hal yang bisa merusak atau mencemari lingkungan yang ada di sekitar, oleh sebab itu awig-awig ini harus di patuhi secara baik sesuai dengan kesepakatan yang telah dibuat.

Jadi, dapat kita pahami bahwa konsep awik-awik desa adalah aturan-aturan atau norma-norma yang berasal dari tradisi yang hidup di tengah masyarakat untuk menjaga lingkungan, sosial budaya dan lainnya berupa anjuran, larangan dan sanksi yang disepakati bersama dan bercorak sesuai dengan tempat tinggalnya, kemudian untuk keberlanjutan awik-awik ini diwariskan kepada generasi berikutnya secara turun-temurun.

\section{Tujuan adanya Awik-awik}

Awik-awik juga berfungsi untuk mengintegrasikan warga masyarakat dalamsuatu persatuan dan kesatuan yang hidup bersama sepenanggungan danseperjuangan, sedangkan arti penting Awik-awik adalah merupakan pengikatpersatuan dan kesatuan krama desa guna menjamin kekompakan dan keutuhandalam manyatukan tujuan bersama mewujudkan kehidupan yang aman, tertib,dan sejahtera di wilayah desa adat.

Edi Muhamad Jayadi dan Soemarno menjelaskan bahwa: Sebagai hukum rakyat yang digunakan untuk mengatur kehidupan masyarakat, hukum adat terus-menerus mengalami perubahan.Perubahan yang terjadidimaksudkan untuk memperkuat kapasitas melalui penguatan struktur danfungsi awik-awik.Penguatan tersebut dilakukan dengan menerbitkan peraturandesa (Perdes) sebagai wadah untuk mengakomodasi perubahan-perubahanbaru yang sebelumnya tidak dicantumkan dalam awik-awik lama.

Tugas paling berat diemban oleh loka awik-awik (Hakim dan pengawas awikawik) yaitu mengawasi pelaksanaan awik-awik dan menyelesaikan masalah awik-awikketika terjadi pelanggaran.

Hasilnya adalah bahwa ketaatan mereka pada awik-awik yang lahir dari kearifanlokal masyarakat setempat, mereka menikmati hasil sebagai berikut:

a. Terpeliharanya berbagai lingkungan sosial dan alam. 
b. Terpeliharanya pohon besar dan tanaman yang ditanam oleh masyarakat, seperti pisang, durian, pepaya dan nangka.

c. Masyarakat dapat memenuhi kebutuhan sehari-hari yang bisa diambil dari alam secara langsung.

d. Masyarakat dapat memenerikan Pendidikan yang layak kepada anakanaknya karena sumberdaya terpelihara dengan baik.

e. Masyarakat bisa menghargai dan melaksanakan kearifan lokal yanghidup sejak nenek moyang hingga keturunannya nanti.

f. Masyarakat dapat melaksanakan nilai-nilai luhur yang sudah terpelihara dari nenek moyang dengan baik, seperti: gotongroyong, menghargai adat-istiadat, memelihara lingkungan alam sebagai sumber hajat hidup orang banyak.

Dengan demikian, Awik-awik dapat dianalisis sebagai adat yangtidak bertentangan dengan hukum', maka boleh diamalkan untuk menjaga dan melestarikan lingkungan hidup manusia.

\section{B. Kajian Tentang Ecopedagogy}

\section{Konsep Ecopedagogy}

Secara etimologi istilah ekopedagogik (ecopedagogy) berasal dari dua kata kata, yaitu ekologi (ecology) yang mengandung arti ilmu yang mempelajari hubungan timbal balik antara makhluk hidup dan lingkungannya, dan pedagogic (pedagogy) yang berarti ilmu pendidikan, baik secara teoretis maupun praksis yang didasarkan pada nilai-nilai filosofis. Berdasarkan tinjauan tersebut, maka dapat dipahami, bahwa ekopedagogik merupakan sebuah pendekatan untuk membangun kesadaran ekologi, berdasarkan refleksi kritis atas kondisi kehidupan yang yang tidak sesuai dengan harapan, guna membangun masa depan kehidupan yang lebih baik.

Dalam konteks ini, ekopedagogik merupakan sebuah gerakan yang berorientasi ke masa depan "untuk mengembangkan apresiasi yang kuat untuk potensi kolektif manusia dan untuk mendorong keadilan sosial diseluruh dunia yang diharapkan akan lahir kesadaran masyarakat dunia akan ekoliterasi kritis (melek lingkungan secara kritis). Hal ini berkorelasi dengan pendapat Supriatna (2016) yang memandang bahwa ekopedagogik sebagai gerakan kembali ke alam dengan menggali kembali nilai-nilai yang terkandung pada warisan budaya mengenai pelestarian alam.

Dalam perspektif yang berbeda secara lebih operasional, Surata (2010), mendefinisikan bahwa ekopedagogik merupakan tipe pembelajaran berbasis cinta, partisipasi dan kreativitas. Ekopedagogik membahas tiga bidang utama. Pertama, ekoliterasi teknis (fungsional) untuk memahami dasar-dasar sains, konsep ekologi dan biologi, serta dampak positif dan negatif manusia terhadap sistem ekologi. Kedua ekoliterasi budaya untuk meningkatkan wawasan, kesadaran dan pemahaman tentang berbagai perspektif budaya dalam hubungan antara manusia dan lingkungan yang menghasilkan keberlanjutan kehidupan. Ketiga, ekoliterasi kritis untuk melibatkan subjek pendidikan terhadap politik ekologi, kemajuan teknologi dan komunikasi melalui dialog yang kritis dan konstruktif.

Terdapat berbagai acuan yang digunakan dalam pengembangan bahan ajar. Pertama, menggunakan tiga pilar ekopedagogi (konsep kelenturan ekologi-sosial, literasi budaya, dan penggunaan teknologi secara kritis dan kreatif (Kahn 2008; 2010). Kedua, membangun keseimbangan antara kemampuan berpikir (head), bersikap (heart), dan bertindak (hand). Ketiga, mendorong pembelajaran sebagai proses sosial untuk mendorong keterampilan sosial siswa dalam berinteraksi baik di dalam kelas, maupun di luar kelas. Keempat, mengarah pada pencapaian komptensi akademik pada tingkat yang lebih tinggi sesuai dengan taksonomi Bloom.

Ekopedagogi tidak terbatas pada aspek kognitif namun mencakup berbagai tantangan, perilaku, sikap, perspektif, kepedulian dan kemampuan untuk merasa terikat dengan 
komunitas manusia (Gadotti 2008; KostoulasMakrakis 2010).

\section{Tujuan Ecopedagogy}

Ekopedagogik merupakan hal esensial yang perlu dikaji dan dipahami, karena ekopedagogik merupakan salah satu isu kritis dalam pedagogik kritis maupun pedagogik transformatif. Dengan mempelajari ekopedagogik kita di perkenalkan bahwa pendidikan tidak hanya mempelajari peserta didik dengan lingkungan manusia saja, tetapi kita diperkenalkan pada lingkungan yang lebih luas lagi. Ekopedagogik dikembangkan diberbagai Negara dalam lingkup global, sebagai bentuk kepedulian bersama dalam masyarakat global (Gyallay, dalam Muhaimin 2014).

Ekopedagogik diperlukan untuk menyadarkan semua pihak akan adanya eksploitasi dari manusia terhadap alam serta eksploitasi kelompok lain yang memiliki kekuasaan terhadap kelompok lainnya. Oleh sebab itu, ekopedagogik sebagai sebuah pendekatan pembelajaran yang didukung oleh teori kritis dan pedagogik kritis menghendaki adanya proses pembelajaran yang memberdayakan peserta didik dari belenggu kekuasaan politik, ekonomi, budaya, serta ideologi-ideologi besar tak terkecuali masalah lingkungan sosial berada di dalamnya. Hal ini sesuai dengan pendapat Tsegay (2016) yang mengungkapkan bahwa "As a critical approach, ecopedagogy enables to educate people connecting environmental and social problems".

Berdasarkan hal tersebut ekopedagogik berorientasi pada kesadaran ekologi dalam multiperspektif sebagai upaya dalam membangun kebijaksanaan atas dimensi kehidupan manusia. Dalam tinjauan yang lebih komprehensif, Gadotti mengungkapkan bahwa: The fundamentals of the eco-pedagogy include protection of nature (natural ecology), the impact of the human societies upon nature (social ecology) as well as the influence over civilization and economic, social and cultural composition (integrated ecology) therefore, essentially it promotes respect for nature, human, culture and diversity (Gadotti, 2008).

Ekopedagogik merupakan proyek kehidupan yang bertujuan mewujudkan citacita ekologi baru-peradaban yang berkelanjutan sehingga anak-anak dan orang muda dapat mewujudkannya dengan bantuan para pendidik dan orang-orang di sekitarnya (Gaddoti, 2002). Dengan mengedepankan paradigma ekopedagogi, manusia tidak melihat dirinya sebagai tuan dan penguasa bumi, melainkan keduanya merupakan bagian dari alam. Dengan kata lain bahwa manusia adalah bagian integral yang tidak bisa dipisahkan dari dan menyatu dengan alam. Dalam istilah lain dikatakan bahwa "Human beings are considered part of the planet" (Freire, 2010; Misiaszek, 2012), Ini artinya bahwa ekopedagogik menyatukan hak manusia dan hak alam (Gadotti, 2010).

Berkaitan dengan hal di atas, (Gyallay, dalam Muhaimin 2014). Mengungkapkan bahwa tujuan ekopedagogik adalah sebagai berikut.

a. Untuk membantu menjelaskan masalah kepedulian serta perhatian tentang saling keterikatan antara eknomoi, social, politik, dan ekologi dikota maupun di wilayah pedesaan.

b. Untuk memberikan kesempatan kepada setiap orang untuk mengembangkan pengetahuan, nilai, sikap, komitmen, dan kemampuan yang dibutuhkan untuk melindungi dan memperbaiki lingkungan.

c. Untuk menciptakan pola perilaku yang baru pada individu, kelompok, dan masyarakat sebagai suatu keseluruhan terhadap lingkungan. Tujuan yang ingin dicapai tersebut meliputi aspek (a) pengetahuan; (b) sikap; (c) kepedulian; (d) keterampilan; dan (e) partisipasi.

Berdasarkan hal di atas, maka dapat dipahami bahwa tujuan ekopedagogik adalah membangun kesadaran kolektif untuk berperan aktif dalam menjaga dan merawat planet bumi, karena alam merupakan ruang pemberi dan pemakna kehidupan (lebenstraum), dan bukan hanya sebagai lingkungan hidup (environment) 
semata. Selain itu, ekopedagogik merupakan pendidikan yang dapat mengubah paradigma ilmu yang hanya dipahami sebagai sesuatu yang bersifat mekanistik, reduksionis, parsial dan bebas nilai menjadi ekologis, holistik dan terikat nilai sehingga dapat tumbuh kearifan (wisdom). Selain itu, ekopedagogik juga merupakan pendidikan untuk mengenali alam, sehingga tumbuh rasa cinta/respek terhadap alam beserta isinya.

Berdasarkan hal di atas, dapat disimpulkan bahwa tujuan ekopedagogik adalah untuk membangun literasi tentang lingkungan (melek lingkungan). Dengan melek lingkungan, kita akan memiliki rasa tanggungjawab untuk menjaga dan merawatnya. Hal ini dipertegas oleh Turner (2011) yang mengungkapkan bahwa "some of the aims of ecopedagogybased environmental education help to improve favourable environmental attitude and awareness, increase environmental knowledge level, have holistic approach towards nature".

C. Prinsip-prinsip implementasi Awik-awik sebagai model "ecopedagogy" dalam pembelajaran IPS

Sebagai basis pendidikan pembangunan berkelanjutan, ekopedagogi menawarkan empat sistem pengajaran: (1) pengajaran tentang lingkungan sosial dan alam, yakni menyiapkan teks-teks terkait lingkungan hidup bagi anak-anak sehingga memampukan mereka menyingkapkan isu-isu lingkungan terkini, akar dari isu, serta strategi untuk menanggapi isu, baik secara individu maupun kolektif; (2) pengajaran dalam lingkungan sosial dan alam, yakni menuntun para pelajar kepada kesadaran akan relasi mereka dengan lingkungan, baik sosial maupun alam; (3) pengajaran melalui lingkungan sosial dan alam, yakni mengadaptasi tugas-tugas kelas, latihan menulis, kerja kelompok, pengalaman, perjanjian dengan masyarakat untuk menjelmakan pengetahuan ke dalam aksi sosial, keadilan lingkungan, kesejahteraan dan keberlanjutan; (4) pengajaran tentang kesalingterkaitan antar makhluk yang berkelanjutan (Surata, 2010).

Dalam implementasinya, Awikawiksebagai model "ecopedagogy" dalam pembelajaran IPS perlu dikembangkan berdasarkan pada prinsip-prinsip dan pendekatan secara komprehensif melalui pembelajaran holistik sebagai berikut.

1. Pembelajaran tidaklah dikembangkan berdasarkan pada orientasi pencapaian domain kognitif semata, melainkan harus mencakup multidomain yang meliputi kgnitif, afektif dan psikomotorik.

2. Pembelajaran berbasis ekopedagogik menekankan pada pengembangan materi yang tidak hanya terbatas pada sesuatu yang bersifat tekstual, melainkan perlu dikembangkan melalui pendekatan kontekstual. Artinya bahwa, pembelajaran secara esensial harus dikembangkan dengan menggunakan sumber dan media yang berada dalam konteks kehidupan peserta didik, agar peserta didik mampu mengosntruksi pengetahuan secara bermakna.

3. Pembelajaran harus berorientasi pada keaktifan dan keterlibatan siswa dalam memecahkan permasalahan secara kooperatif maupun kolaboratif. Adapun tujuannya ialah mengembangkan keterampilan berpikir kritis peserta didik untuk menganalisis berbagai permasalahan dalam kehidupannya dan mampu mengambil solusi atas permasalahan tersebut secara bijaksana serta mengembangkan karakter peserta didik.

4. Pembelajaran harus berbasis pada pendekatan interdisipliner dalam rangka memperkaya pengetahuan dan pemahaman peserta didik secara komprehensif.

Berdasarkan hal di atas, dapat dipahami bahwa implementasi Awik-awiksebagai model "ecopedagogy" dalam pembelajaran IPS tidaklah berbasis pada pendekatan konservatif, melainkan perlu dikembangkan secara komprehensif melalui berbagai pendekatan yang mampu menunjang efektivitas pelaksanaan kegiatan pembelajaran. 
D. Aplikasi Awik-awik sebagai model "ecopedagogy" ke dalam Pembelajaran IPS

Pembelajaran IPS yang dikaitakan dengan penggunaan awik-awik sebagai model ecopedagogy, dalam penulisan makalah ini didasarkan pada kompetensi dasar pendidikan IPS pada kelas 7 SMP. Dipilihnya komptensi dasar pada kelasa 7 ini karena keterkaitnya dengan judul atau tema makalah yang diangkat yakni pembalajatan IPS yang berkaitan dengan alam dan lingkungan. Dimana kompetensi dasar pada jenjang tersebut yakni; 1) Memahami konsep ruang (lokasi, distribusi, potensi, iklim, bentuk muka bumi, geologis, flora dan fauna) dan interaksi antarruang di Indonesia serta pengaruhnya terhadap kehidupan manusia dalam aspek ekonomi, sosial, budaya, dan pendidikan, 2) Menganalisis interaksisosial dalam ruang dan pengaruhnya terhadap kehidupan sosial, ekonomi dan budaya dalam nilai dan norma serta kelembagaan sosial budaya, dan 3) Menganalisis konsep interaksi antara manusia dengan ruang sehingga menghasilkan berbagai kegiatan ekonomi (produksi, distribusi, konsumsi, penawaran permintaan) dan interaksi antarruang untuk keberlangsungan kehidupan ekonomi, sosial dan budaya Indonesia.

Mengacu pada kompetensi dasar pendidikan IPS kelas 7 di atas sebagai basis pendidikan pembangunan berkelanjutan, pendidikan IPS yang disandingkan dengan kosep ekopedagogi menawarkan empat sistem pengajaran:

1. Pertama, pengajaran tentang lingkungan sosial dan alam, yakni menyiapkan teksteks terkait lingkungan hidup bagi siswa kelas 7 sehingga memampukan mereka menyingkapkan isu-isu lingkungan terkini, akar dari isu, serta strategi untuk menanggapi isu, baik secara individu maupun kolektif.

2. Kedua, pengajaran dalam lingkungan sosial dan alam, yakni menuntun para siswa kepada kesadaran akan relasi mereka dengan lingkungan, baik sosial maupun alam. Pembelajaran IPS kelas 7 dirancang mengambil tempat di luar ruangan kelas seperti di jalan-jalan, sungai-sungai kecil dan besar, hutan, gunung, samudera, termasuk pengalaman dan perspektif tentang binatang dan keanekaragaman budaya lain.

3. Ketiga, pengajaran melalui lingkungan sosial dan alam, yakni mengadaptasi tugastugas kelas, latihan menulis, kerja kelompok, pengalaman, perjanjian dengan masyarakat untuk menjelmakan pengetahuan ke dalam aksi sosial, keadilan lingkungan, kesejahteraan dan keberlanjutan.

4. Keempat, pengajaran tentang kesalingterkaitan antarmakhluk yang berkelanjutan. Pembelajaran IPS Melalui model ekopedagogi, kita dapat mengetahui bagaimana secara global menghentikan kekuatan yang menghancurkan sistem kehidupan dan masyarakat; bagaimana bertindak untuk mentransformasi dan memperbaiki kehidupan dan komunitas kita hari ini dan besok; bagaimana mengorganisasi manajemen dan politik atas udara, air, makanan, hutan dan masa depan orang banyak dan menjamin ketersediaan sumber daya alam bagi kebutuhan manusia dan makhluk lainnya.

Surata (2010), mendefinisikan bahwa ekopedagogik merupakan tipe pembelajaran berbasis cinta, partisipasi dan kreativitas. Ekopedagogik membahas tiga bidang utama. Pertama, ekoliterasi teknis (fungsional) untuk memahami dasar-dasar sains, konsep ekologi dan biologi, serta dampak positif dan negatif manusia terhadap sistem ekologi. Kedua, ekoliterasi budaya untuk meningkatkan wawasan, kesadaran dan pemahaman tentang berbagai perspektif budaya dalam hubungan antara manusia dan lingkungan yang menghasilkan keberlanjutan kehidupan. Ketiga, ekoliterasi kritis untuk melibatkan subjek pendidikan terhadap politik ekologi, kemajuan teknologi dan komunikasi melalui dialog yang kritis dan konstruktif. 
Terdapat berbagai acuan yang digunakan dalam pengembangan bahan ajar. Pertama, menggunakan tiga pilar ekopedagogi (konsep kelenturan ekologi-sosial, literasi budaya, dan penggunaan teknologi secara kritis dan kreatif (Kahn 2008; 2010). Kedua, membangun keseimbangan antara kemampuan berpikir (head), bersikap (heart), dan bertindak (hand). Ketiga, mendorong pembelajaran sebagai proses sosial untuk mendorong keterampilan sosial siswa dalam berinteraksi baik di dalam kelas, maupun di luar kelas. Keempat, mengarah pada pencapaian komptensi akademik pada tingkat yang lebih tinggi sesuai dengan taksonomi Bloom.

Sebagai basis pendidikan pembangunan berkelanjutan, ekopedagogi menawarkan empat sistem pengajaran:

1. Pengajaran tentang lingkungan sosial dan alam, yakni menyiapkan teks-teks terkait lingkungan hidup bagi anak-anak sehingga memampukan mereka menyingkapkan isuisu lingkungan terkini, akar dari isu, serta strategi untuk menanggapi isu, baik secara individu maupun kolektif;

2. Pengajaran dalam lingkungan sosial dan alam, yakni menuntun para pelajar kepada kesadaran akan relasi mereka dengan lingkungan, baik sosial maupun alam;

3. Pengajaran melalui lingkungan sosial dan alam, yakni mengadaptasi tugas-tugas kelas, latihan menulis, kerja kelompok, pengalaman, perjanjian dengan masyarakat untuk menjelmakan pengetahuan ke dalam aksi sosial, keadilan lingkungan, kesejahteraan dan keberlanjutan;

4. Pengajaran tentang kesalingterkaitan antar makhluk yang berkelanjutan (Surata, 2010).

Dalam implementasinya, pendidikan berbasis ekopedagogik perlu dikembangkan berdasarkan pada prinsip-prinsip dan pendekatan secara komprehensif melalui pembelajaran holistik sebagai berikut.

1. Pembelajaran tidaklah dikembangkan berdasarkan pada orientasi pencapaian domain kognitif semata, melainkan harus mencakup multidomain yang meliputi kgnitif, afektif dan psikomotorik.

2. Pembelajaran berbasis ekopedagogik menekankan pada pengembangan materi yang tidak hanya terbatas pada sesuatu yang bersifat tekstual, melainkan perlu dikembangkan melalui pendekatan kontekstual. Artinya bahwa, pembelajaran secara esensial harus dikembangkan dengan menggunakan sumber dan media yang berada dalam konteks kehidupan peserta didik, agar peserta didik mampu mengosntruksi pengetahuan secara bermakna.

3. Pembelajaran harus berorientasi pada keaktifan dan keterlibatan siswa dalam memecahkan permasalahan secara kooperatif maupun kolaboratif. Adapun tujuannya ialah mengembangkan keterampilan berpikir kritis peserta didik untuk menganalisis berbagai permasalahan dalam kehidupannya dan mampu mengambil solusi atas permasalahan tersebut secara bijaksana serta mengembangkan karakter peserta didik.

4. Pembelajaran harus berbasis pada pendekatan interdisipliner dalam rangka memperkaya pengetahuan dan pemahaman peserta didik secara komprehensif.

Melalui awik-awik sebagai model "ecopedagogy"dalam pembelajaran IPSyang dilaksanakan di sekolah, program lingkungan hidup dapat diimplementasikan dalam kurikulum sekolah. Implementasi program lingkungan hidup dalam kurikulum diharapkan dapat menciptakan perubahan, baik perubahan sikap maupun pengetahuan serta mampu membentuk kepribadian peserta didik untuk menjadi lebih baik. Upaya yang dilakukan sekolah untuk mewujudkan kepedulian peserta didik terhadap lingkungan hidup yakni, sekolah berupaya untuk memasukkan program lingkungan hidup ke dalam kurikulum.

Berbagai bentuk awik-awik yang bisa ditawarkan untuk dimasukkan kedalam kurikulum Pendidikan IPS disekolah antara lain dapat berupa berbagai contoh awik-awik yang telah dibuat oleh para leluhur serta 
kesepakata yang telah dibuat oleh masyarakat untuk menjaga serta melestasikan lingkungan sosial dan alam, seperti:

1. Awik-awik awik yang dibuat oleh masyarakat pesisir pantai

Awik-awik yang dibuat dalam rangka memperbaiki pengelolaan sumber daya perikanan pantai di Lombok sebagai sebuah upaya agar dalam pemanfaatan sumber daya perikanan bisa berlangsung secara berkelanjutan baik secara ekonomi dan ekologi.Awik-awik pengelolaan sumber daya perikanan Lombok sebagai sebuah peraturan yang berfungsi untuk memberikan kejelasan mengenai kejelasan batas pengaturan, kesesuaian peraturan dengan kondisi Lokal, pengaturan secara kolektif, monitoring, pemberian sangsi, dan sebagai alat adalam mekanisme penyelesaian konflik.

2. Awik-awik yang dibuat oleh masyarakat Lombok yang bertempat tinggal dekat hutan produksi dan hutan taman nasional.

Awik-awik ini lahir berdasarkan pentingnya menjaga kelestarian hutan dan diiringi dengan meningkatkan kesejahteraan masyarakat sekitar hutan. Atas dasar ini pada tahun 1986 Gubernur NTB mengeluarkan surat keputusan No. 140 tahun 1986 tentang pemanfaatan tanaman kopi dalam areal hutan di wilayah Provinsi Daerah Tingkat I NTB, isi/materi awik-awik terdiri dari anjuran, larangan dan sanksi, pada tahap pelaksanaan melibatkan seluruh anggota masyarakat.

3. Awik-awik dalam lingkungan sosial

Awik-awik dalam lingkungan sosial masyarakat pada masyarakat Lombok tergolong sangat komplit dan bahkan sangat banyak. Diantara awik-awik yang dibuat oleh masyarakat salah satunya adalah banjar mate. Tujuan Lembaga Banjar Kematian adalah a) menerapkan ajaran agama secara utuh dalam penanganan kematian sesuai ajaran agama Islam, b) menyemarakkan Fardu kifayah dlam menyolatkan penguburan pemakaman jenazah, c) mempererat silaturrahmi sesama muslim, dan d) membantu sesama sebagai mahluk Allah SWT.

Dapat dipahami pula bahwa implementasi awik-awik sebagai model ekopedagogik dalam pembelajara IPS tidaklah berbasis pada pendekatan konservatif, melainkan dikembangkan secara komprehensif melalui berbagai pendekatan yang mampu menunjang efektivitas pelaksanaan kegiatan pembelajaran. Dengan demikian kesimpulan yang dapat dipetik adalah kompetensi ecopedagogy merupakan upaya dalam membangun karakter peserta didik agar mampu menjadi manusia bijaksana dalam menjalani hidup dan kehidupannya, khususnya dalam memahami hakikatnya sebagai makhluk multidimensional yang salah satunya ialah memiliki relasi dalam dimensi ruang dan waktu dengan alam.

\section{KESIMPULAN}

Berdasarkan penjelasan di atas, maka dapat dipahami bahwa awik-awik sebagai model ekopedagogik merupakan suatu pendekatan yang berorientasi pada upaya pengembangan multidomain siswa secara bermakna. Artinya bahwa pembelajaran tidaklah dikembangkan berdasarkan pada orientasi pencapaian domain kognitif semata, melainkan harus mencakup multidomain yang meliputi kognitif, afektif dan psikomotorik. Berdasarkan pada prinsip pengembangannya, pembelajaran berbasis ekopedagogik menekankan pada pengembangan materi yang tidak hanya terbatas pada sesuatu yang bersifat tekstual, melainkan perlu dikembangkan melalui pendekatan kontekstual. Artinya bahwa, pembelajaran secara esensial harus dikembangkan dengan menggunakan sumber dan media yang berada dalam konteks kehidupan peserta didik, agar peserta didik mampu mengosntruksi pengetahuan secara bermakna. Berdasarkan hal tersebut, pembelajaran harus berbasis pada pendekatan interdisipliner dalam rangka memperkaya pengetahuan dan pemahaman peserta didik secara komprehensif. Selain dari itu, pendidikan berbasis ekopedagogik beroerientasi pada pencapaian pemahaman secara utuh tentang hakikat manusia dan alam yang memiliki relasi 
esensial, sehingga hal ini berimplikasi pada tumbuhnya kesadaran kritis dan terbangunnya karakter peserta didik.

\section{DAFTAR PUSTAKA}

Capra, Fritjof. 1997. Titik Balik Peradaban-Sains, Masyarakat dan bangkitan Kebudayaan. Bentang Pustaka.

Hana Yunansah1 dan Yusuf Tri Herlambang (2017). Pendidikan berbasis ekopedagogik dalam menumbuhkan kesadaran ekologis dan mengembangkan karakter siswa sekolah dasar Sebuah telaah kritis dalam perspektif pedagogik kritis. Eduhumaniora: jurnal Pendidikan Dasar. Vol. 9. No.1

Jakiatin Nisa, dkk. (2017). Identifikasi

Pembelajaran IPS Berbasis Literasi
Geografi dalam Menumbuhkan Karakter Peduli Lingkungan Peserta Didik. Sosio Didaktika: Social Science Education Journal, 4 (1), 2017, 1-13

Muhaimin. (2014). Membangun Kecerdasan Ekologis. Bandung: Alfabeta.

Sang Putu Kaler Surata. (2013). Pembelajaran Lintas Budaya: Penggunaan Subak sebagai Model "Ecopedagogy. Jurnal Kajian Bali Volume 03, Nomor 02.

Supriatna, N. (2016). Ecopedagogy. Bandung: Rosdakarya.

Surata, K. (2010). Pembelajaran Lintas Budaya: Penggunaan Subak sebagai Model "Ecopedagogy". Jurnal Kajian Bali. 03, (02). 